\title{
Salafi Puritanism in Indonesia
}

\author{
Ahmad Syamsir' ${ }^{1}$, Muhammad Andi Septiadi2 ${ }^{*}$, Muhamad Ilham Nurhakiki ${ }^{3}$, \\ Muhammad Ihsan al-Habsy", Muhammad Rizal Arifin Hidayah ${ }^{5}$ \\ 1-5UIN Sunan Gunung Djati Bandung, Indonesia \\ *Corresponding Author E-mail: Septiadi.andi90@uinsgd.ac.id
}

\begin{abstract}
Salafis are known for their puritanical attitudes and thoughts. They strongly desire to purify Islamic teachings by inviting people to avoid shirk, heresy, and superstition. This makes them trapped in these stigmas, thus making them often come into conflict with groups that are opposite to them. Especially when this Salafi understanding came to Indonesia, when they began to spread his puritanical teachings, they were immediately rejected. This study aims to understand the theological instructions adopted by Salafi figures both abroad and domestically. This type of research is qualitative by using secondary data sources and using the Geisteswissenschaften analysis technique developed by Wilhelm Dilthey, which is often used to analyze religious texts of puritan groups using an interpretative approach. In addition, we also conducted observations using non-participatory methods in communities that claim to be Salafi. This study states that Salafis's theology is very rigid and tends only to understand the text according to personal interpretation. This study also finds that people do not really understand the teachings of Salafis as a whole but only take refuge behind the name of Salafis. This research encourages the Ministry of Religion and MUI to be more active in maintaining unity in Islam, although there are some differences of opinion. And also encourage the public to enrich Islamic literature more to be more tolerant in understanding differences.
\end{abstract}

Keywords: Salafi, Puritan, Theology, Islam

\section{INTRODUCTION}

One way to invite Muslims to the right and straight path is to preach (Ali \& Minxing, 2021). Da'wah is one method of enjoining ma'ruf nahi munkar. For this reason, in preaching, it is necessary to have clear planning and goals so that the goals and objectives of da'wah (mad'u) are achieved. In preaching, it is not uncommon for the preacher to insert the teachings he brings so that the listeners follow the teachings in question. This has resulted in the emergence of many religious sects in Indonesia, both radical and nonradical, both moderate and liberal. This is based on the many differences that arise among Muslims. As happened in the mid-1980s, the Salafi community began to spread its ideas and ideas to the general public. Moreover, when the New Order government collapsed, they seemed to get a breath of fresh water because they had a gap to enter the world of politics to make it easier for them to spread their teachings. They also enthusiastically invite people to return to the Qur'an and Sunnah by the understanding of friends in every aspect of life. And this is one proof of the spread of Islamic puritanism in the political landscape of postNew Order Indonesia (Baskara, 2017). The problem here, the results of the initial study. They are too narrow in understanding the Nash and only want to accept the understanding of the Salaf generation according to their tastes. They start blaming people who are different from their understanding. When Islam spreads throughout the world, the teachings of Islam will also be influenced by the culture of the area. The teachings of Islam will filter by itself which culture is contrary to the Shari'a and which culture is not against the Shari'a. Now here is the problem, the Salafi group immediately claimed that culture should not be included in the teachings of Islam. Whereas, as mentioned earlier, culture is not always in conflict

* Copyright (c) 2021 Ahmad Syamsir et.al

This work is licensed under a $\underline{\text { Creative Commons Attribution-ShareAlike 4.0 International License. }}$

Received: Juny 5, 2021 ; Revised: Juny 25, 2021 ; Accepted: July 4, 2021 
with the Shari'a. Even in Usul Fiqh it is explained that culture can enter into the Shari'a, so this is called 'Urf. Now, because the Salafis do not adhere to any of the four schools of thought (Hanafi, Maliki, Shafi'i, and Hanbali), the Salafis also forbid taqlid to the Imams of the schools and easily call people who contradict their understanding as heretics and will go to hell (Zargar, 2014). Now this is their fault for mixing up the understanding of fiqh that is still in ikhtilaf into the aqidah chapter. For example, they say that qunut is bid'ah, and whoever commits heresy will go to hell. This is what often causes endless conflicts between Salafi groups and Muslim majority groups in Indonesia such as Nahdlatul Ulama and Muhammadiyah.

Wahabi teachings first entered Indonesia through the Minangkabau area. Wahhabi thought slowly began to enter Indonesia massively through the role of the Indonesian Islamic Da'wah Council (DDII) which was founded by Muhammad Natsir. This institution sends many students to the Middle East to study Islam through financial support from Saudi Arabia. Saudi Arabia also assisted in establishing the Institute for Islamic and Arabic Sciences (LIPIA) in 1981 whose curriculum followed the al-Imam Muhammad bin Suud al-Islamiyyah University in Riyadh. From LIPIA, Salafi da'wah cadres were born in Indonesia. Through LIPIA, many students are sent to Saudi Arabia every year to study Islam (Baskara, 2017). The previous Salaf al-Salih scholars were Ibn Taimiyah (1263-1328), Ibn Qayyim al-Jauziyah (1292-1350), Husein al-Dzahabi (1284-1348), Ibn Kathir (1300-1373), Muhammad bin Abdul Wahhab (1703-1792), and modern scholars, such as Abdul Aziz Bin Baz (1912-1999), and Muhammad Nashiruddin al-Albani (1914-1999). Equating Salafis with Wahhabis is a bit ambiguous and confusing at first glance. Wahhabism is a term for those who follow the teachings of Muhammad bin Abdul Wahhab. While the term Salafi existed long before the Wahhabi founder was born (Chozin, 2013). Salafis themselves also claim to be members of the Ahlusunah wal Jama'ah group. The Salafi version of Ahlusunah wal Jamaah's teaching itself is against the practice of heresy and asks Muslims to return to the Koran and Hadith. Traditions that are regarded heretical by him are traditions such as maulid, manaqib, haul, tawasul, yasinan, tahlilan, talqin, neloni, mitoni (pre-birth of a child), selapan (post-birth salvation), and others by writing on the Web. The publications that they produce and publish to obtain sympathy from the public with Ahlusunah wal Jama'ah's truth are considered to be true (Chozin, 2013).

Research conducted by Chozin (2013) examines the Salafi da'wah strategy. It explains the origins of the Salafi, the media used by Salafi in preaching, and the methods used by Salafi in disseminating their teachings. Then the research conducted by Baskara (2017) examines Puritan Islam in Indonesia wherein it is explained about the beginning of Salafi and its development in Indonesia. Furthermore, research conducted by Hidayat (2012) examines the Salafi da'wah movement in Indonesia in the Reformation Era, where the author conveys how Salafis as a movement have the capacity of ideas and ideals that guide each action. The idea of "pure Islam" consistently campaigns as part of the movement's goal to live a life according to what the Prophet and his Companions had exemplified. The following research is research conducted by Madali (2021) which examines the religious experience of the Wahhabi Salafi perspective, which contains in it how Da'wah is carried out by Salafi scholars such as Muhammad ibn 'Abd al-Wahhāb and others. The last research is research conducted by Maksum et al (2020), examining the ahlussunnah wal Jamaah conflict between NU and Salafi. This study uses a sociological approach, namely understanding Islamic studies with a sociological perspective. The Islamic study in question discusses the conflict for influence between the NU elite and the Salafis from a sociological perspective, namely conflict theory. In understanding the phenomena mentioned above, the researcher also uses Alfred Schutz's phenomenological approach, which can translate phenomenology into sociology, especially in religious studies. 
Several things have not been explained in detail from several previous studies. First, the clear dissection of puritan, radical, and fundamental Islam in Islam has not been clearly explained, thus allowing for ambiguity in understanding the three terms. Two, from several previous studies that have not discussed the theological differences between Salafis and Ash'ari (the theology adopted by the majority of Indonesian Muslims), we will dissect the differences between these two theologies. We do this because differences in the theological realm are very sensitive and allow conflicts to occur if they are not resolved amicably. Third, we will explain the relationship between foreign Salafis and domestic Salafis. At the same time, in the journal described above, we do not discuss Salafi figures abroad, such as Muhammad Ibn 'Abd al-Wahhāb (1703-1791 AD). Muḥammad Nāșir al-Dn al-Albānī (1914-1999 AD); Ibn al-'Uthaymin (19292001 AD); and âlih al-Fawzān (1933-present). Fourth, we will look for some similarities between the Salafi group and the NU group and other moderate groups to synthesize the Salafi understanding and the understanding of the moderate groups in Indonesia. It is hoped that with this research, the public will be more open to the very complex world of Islamic thought. So that way, we will understand each other about the differences in Islamic manhajs.

\section{RESEARCH METHOD}

Many things can be identified from the puritan movement that entered Indonesia. But so far, the theological perspective has received little attention. The theological aspect is the main source that encourages a group to become puritanical. Attitudes that tend to disbelieve "or at least to heresy" groups who disagree with them are not just fiqh alone. This attitude is closely related to theological issues that become one's perspective on one's faith status. This way of understanding can cause reactions that can lead to an uproar. This is what often happens in Indonesia, where the majority Muslim group feels "disturbed" by the ideas propagated by Salafis (Madali, 2021). Thus, the question will arise, "What are the theological teachings that are the basis of Salafi puritanism?"

Theological issues become more colorful when associated with the political or social background of a character or movement. But the impetus from the theological view is "basically" enough to explain the puritanism of a group. All of this can be completed by tracing the genealogy of the characters caught in the group (Hasyim, 2019).

Based on that, we will try to trace the genealogy of Salafi puritan theology, especially world Salafi leaders and Salafi figures who spread their teachings in Indonesia. But to make it easier for us to do this, we also limit the world Salafi figures that we will discuss to four figures, namely Muhammad Ibn 'Abd alWahhab (1703-1791 AD) Muhammad Nashiruddin al-Albani (1914-1999 AD). ); Ibn al-'Uthaymin (19292001 AD); and Salih al-Fauzan (1944-present). The Salafi figures who preach in Indonesia that we will discuss include: Yazid bin Abdul Qadir Jawwas, Abdul Hakim Abdat, and Khalid Basalamah. We do this because the Salafi figures who spread their da'wah in Indonesia cannot be separated from the influence of Salafi figures who come from abroad so that their scientific chain is continued and their teachings are the same This will raise the question, "How do they spread Salafi teachings in Indonesia and what is the relationship between Salafis abroad and Salafis at home?

Among the various Salafi methods in spreading their understanding is distributing free books when the pilgrims want to return to their home countries, under the pretext of "souvenirs" from the holy land (Putuhena, 2007). In addition, also through education. Education turned out to be the main mediator in grounding imported theologies, including Salafi puritanism. Thus, the question will arise, "How do they influence the community, especially the younger generation, so that many sympathize with Salafi da'wah?" 
This research belongs to the qualitative type with data collection based on library research materials. Direct observation of da'wah activities carried out by Salafi clerics in mosques and observations that we will do on social media are often used in carrying out their da'wah. For direct observation, we will do this in three areas, namely Jambi, Sumedang, and Garut. We chose the three areas based on the number of members of our group and the place where each of us lived. The observation method that we will use is non-participatory. This is because we want the data we get to be of higher quality and seem natural so that the accuracy of the data can be guaranteed. We will do this direct observation for two weeks starting from the beginning of Ramadan because usually, in Ramadan, they will do many da'wah safaris, especially in the areas we observe.

This research uses a theological approach that is strengthened by historical review in analyzing religious texts. The text is not limited to only theological issues but also fiqh associated with issues of belief. The approach used in analyzing the research materials is historical-theological. This is because a text in this context is not "live" if it is only read in a theological framework, and at the same time, ignores historical aspects. In analyzing data, an interpretation of a text is carried out, or it can be called an interpretative approach, especially if it is related to theological aspects (Kaelan, 2010). Therefore, the theory of Geisteswissenschaften Wilhem was borrowed to understand the dynamics of problems implied in the text as part of human history. Geisteswissenschaften, or the science of humanity proposed by Wilhem Dilthey is more appropriate to use in reading texts containing puritan ideology to reveal the other side of the limited appearance of the text. This methodology is very good at bringing out the deepest expressions of humanity with objective validity. This is done by the verstehen procedure or the immersion of meaning from within the text. Therefore, Wilhem Dilthey's approach looks superior in treating a text to be more alive (Palmer, 1969).

The sources that we use in conducting this research are secondary sources related to the study of the teachings of Salafi theology, such as: Puritan Muslim Theology Genealogy and Salafi Teachings by Arrazy Hasyim; The Book of Tawhid by Muhammad Ibn 'Abd al-Wahhab; Honor with the Manhaj Salaf by Yazid bin Abdul Qadir Jawas; Some of Aceng Zakarya's works such as the Science of Tawheed Volume 2, Fundamentals of Tawheed Science volumes 1-3, al-Hidayah fi Masaqil Fiqiyah muta'aridhah, Study of Thoughts of Heretical and Misleading Schools, The Meaning of Returning to the Qur'an and As- Sunnah; some of Tiar Anwar Bahtiar's works such as Luxury Suits: Never Forget History and Da'wah, and The Battle of Islamic Thought in Indonesia: a critique of liberal Islam; The Muslim Faith The Basic Foundation of the Ahlussunah wa al-Jama'ah Faith by Zainal Abidin bin Syamsudin; several works by Hamid Fahmi Zakarsy such as Minhaj Islam from Ritual to Intellectuals, Liberalism of Islamic Thought Movement with Missionaries and Orientalists, Worldview of Islam and Western Capitalism, Traditions of Orientalism and Framework for the Study of the Qur'an; Hamka's Divine Philosophy; Get to know the Salafi Manhaj by Salim bin 'Id al-Hilali.

In addition to sources from books, we also took several credible websites that participated in spreading Salafi teachings, such as www.manhajul-anbiya.net, www.audiokajian.com, and www.salafy.or.id. In addition to web sources, there are also several youtube channels such as Audio Salafi True, Study Salaf Channel, Salafiyun TV, Minang Bertauhid, and Manhaj Salaf. 


\section{RESULTS AND DISCUSSION}

\section{Observation}

In the results of observations spread to three different places, namely, Sumedang, Jambi, and Garut, there are the following results:

\section{Observations of the Sumedang area :}

There are plenty of da'wah activities or studies for the puritanism movement to be found, but the discussion or material presented rarely touches theological discourse. Observations were made from the 1-20th day of Ramadan, although there were several times the preachers presented material on theology. Among them discusses the obligatory nature of Allah and faith and reason. Discussion about the obligatory nature of Allah in the material delivered by one of the Ustadz on Wednesday, April 28, at the al-Barokah mosque in Cintamulya village, Jatinangor sub-district. The essence of the matter that He conveys is that God is obligatory. His existence is certain, not a possible existence, not as a creature whose existence is possible. The creature may never exist for one reason or another. But Allah is obligatory. He can not exist because the absence of God means the absence of creatures.

The discussion on faith and reason was delivered by Ustadz Ridwan on Friday, April 30, at Madrasah al-Wustho, Jatimukti village, Jatinangor sub-district. In the discussion, material about the level or level of knowledge is first described. Knowledge at the first level is only knowing without understanding the meaning, which is only in the form of memorizing. At the second level, the memorization is processed into an understanding. At the third level, understanding is then analyzed, criticized, or synthesized with other understandings until an original understanding is born. And at the fourth level, after there is an original understanding from within, then at this stage is knowledge in practice, namely a practice that is carried out based on awareness or called Surti. It is at the second level that the minimum creed is present in oneself. Because faith requires an understanding, a person can't believe without understanding what He believes in. It is understanding that produces belief. At the last level, namely level four, that is where worship can be done very easily, without the need for coercion and outside elements to do it, because understanding has become a practice, namely Surti.

Discourse on theology is very rarely found in the puritanism movement studies in the Sumedang area. Most of the observations discuss many things related to worship, such as prayer, fasting, and tadarus al-Qur'an. However, the two studies above seem sufficient for me to present in a study like this.

\section{Jambi Regional Observation Results:}

Starting from the first day of Ramadan until the 20th day, we have made observations on Salafi da'wah activities in Jambi province, especially the Jambi city area. We did not get many findings from this observation considering the difficulty of finding da'wah activities such as recitations and the like, in contrast to other areas such as in Sumedang where da'wah activities are quite easy to find in the holy month of Ramadan this year. We also assume this is due to the Covid-19 pandemic, which is thought to cause the absence of recitations/tausyiah in Jambi City this Ramadan, the same as Ramadan in the previous year. However, worship activities that usually take place during Ramadan, such as tarawih prayers, can still be found in almost every mosque in Jambi, even though they are carried out with stricthealth protocols such as the use of masks and social distancing. The tarawih this year is also distinct from prior tarawihs. As we discovered in prior years when Covid-19 did not exist, the average mosque in the city of Jambi 
performed 11 rakaat of tarawih prayers, although tarawih was implemented with 23 cycles virtually every year in the city of Jambi.

As a da'wah movement inheriting the Wahabiyyah tradition, the Salafi da'wah movement is known as a da'wah movement with a radical puritan theological ideology. The call to return to the Qur'an and the Sunnah of the Prophet is the main agenda of this puritan da'wah. To understand the Qur'an and Hadith, these people adhere to literal interpretations and avoid speculative forms that rely on reason. Although ideology is not the only factor that plays a role in social movements, ideology has an important role in raising the awareness of movement members. As for the Salafis, we found in Jambi City that they are divided into two groups. There are straight-line Salafis where they are gentle to groups different from them, but Salafis are very strict and do not want to compromise in holding the principles of Salafi doctrine. They do not hesitate to criticize and view other groups as misguided who are seen as not practicing religious teachings by their basic rules. The title of expert heresy is one of the accusations they often issue to attack other groups. It is this hard group that, based on our observations during Ramadan this year, does not appear to be developing significantly since, in terms of tarawih implementation, Salafi people prefer to do their tarawih prayers at home rather than in congregation, despite the fact that some do it in congregation. Participate in the congregational tarawih prayer at the mosque. This is the reason for our conclusion for this observation that Salafi da'wah and the development of Salafis in Jambi city are still not as fast as in other areas despite our limitations in researching in the midst of the Covid-19 pandemic.

\section{Results of Observations of the Garut Region:}

From my observations in the Garut area, it is very difficult to find studies specifically and discuss theology. Of the approximately 17 mosques observed, all of them only focused on explaining the merits and sins, the virtues of reading the Koran, tahsin, alms, and various other themes that did not seem to lead to the material objects we took. And we also found some things that found interesting, namely that the Salafi clerics who preached in the mosques that we observed seemed to have no understanding of the theology adopted by Ibn Taimiyah. And not infrequently, some claim to be Salafi and feel great with the name, but their doctrines are completely different from the Salafis initiated by Ibn Timiyah. And what's even more interesting is that sometimes they don't even know who Ibn Taimiyah Rahimaullah is.

Thus, we conclude that the development of Salafi da'wah, especially in the Garut area, has not been too massive. And sometimes, many claims to be Salafi sects but do not understand the teachings brought by the Salafis.

\section{Observations on youtube}

We limit our observations on YouTube to five channels which we think can represent all of them. The channels that we observe are true Salafi audio, salaf channel studies, Salafiyun tv, minang tawhid, and manhaj salaf. In observing the true salafy channel, we found the following results, this channel has uploaded 591 videos and has 12.9 thousand subscribers, but this channel has not uploaded new videos for more than four months. Nevertheless, this channel in 2019-2020 has been actively uploading videos on fiqh issues, such as the law on listening to music, building graves, and the law on saving money on go-pay and ovo. In this channel, it is very clear that they forbid all that. The first is the law of listening to music. According to the music is the voice of the devil, and it is forbidden to listen to it, the second, the law of building graves is unlawful because it is based on a hadith, and thirdly, the law of saving money on go-pays or ovo is unlawful because it includes into usury. This channel does not only discuss fiqh issues; there are several times when this channel discusses theological issues, such as those discussed in the video entitled 
the basic principles of aqidah ahlusunah waljama'ah, which consists of three sessions, the first of which is one hour long, but the second and third of which are 50 minutes and 11 minutes, respectively. The essence of the main principles of aqidah conveyed in this channel is an invitation to return to the main source of Islam, namely the Qur'an and Sunnah. This creed does not bind itself to any particular clerical figure. Although in practice they follow the teachings of Muhammad bin Abdul Wahab and ibn Taimiyyah, in essence, they refer back to the Qur'an and the Sunnah of the Prophet.

The next channel is a salaf channel study. This channel has uploaded 95 videos, has 43.3 thousand subscribers, and has been watched 3,070,746 $\mathrm{x}$. This channel has not uploaded videos since 10 months ago, most of the channel videos contain questions about fiqh and theology. However, in contrast to the previous channel, this channel is mostly presented with clerics who are strict in their preaching, and the issue of heresy is a frequently discussed discourse. Bid'ah practices are a form of misguidance and misguidance in hell, which they discuss in each video. There is zero tolerance for heresy, and its main mission is to clean up sinful practices that are considered deviant in religion.

The third channel that we observe is Salafiyun TV, which has uploaded 349 videos and has 53.2 thousand subscribers. Although this channel often actively uploads new videos to this day, the number of views is not as much as the previous channels, which only amounted to 330,787 views. In each video, the issue of fiqh becomes the main topic of discussion, and most of the lectures in this video are delivered by Dr. Firanda Andirja and Farhan Abu Furaihan, these two people are often called Salafi figures who are the most vocal in voicing their ideas. Firanda Andirja talks a lot in each of her videos about the fiqh of Ramadan, such as the law of eye drops during fasting, the law of tarawih, and so on related to Ramadan issues in general. However, in the Salafi schools, their legal provisions are much more lax in this regard than in other schools. For example, their tarawih only amounts to eight raka'at plus witr three raka'at, so there are 11 cycles. Before entering the month of Ramadan, this channel uploaded a lot of videos about theological issues, almost every video was delivered by Dr. Sufyan Baswedan, like God above, equates God's nature with creatures, God's face, and so on. The issue of heresy is also often the subject of study before the arrival of the month of Ramadan. This study was presented by Salim Yahya Qibas and Abdul Hakim Amir Badat in their videos which last 10-15 minutes on average.

The fourth channel is manhaj salaf, which has only uploaded 58 videos and has 2.45 thousand subscribers. Most of the speakers in this channel are Firanda Andirja, Yazid bin Abdul Qadir Jawas, Khalid Basalamah, and Abu Yahya Badrussalam. Fiqh is the subject of discussion in this channel, but this channel is easier to heresy and forbids a case unlike the previous channels. In addition, this channel also presents more discussions about Shafi'i and Sufism teachings. The discussion of the Shafi'i school is always or often brought up by Firanda Andirja, and Yazid bin Abdul Qadir Jawas often bring up the issue of Sufism. As if he did not know the slightest tolerance, his harsh speech has become the hallmark of Yazid.

The last channel, Minang bertauhid, is the channel that has the most subscribers than the other four channels. This channel has 138 thousand subscribers and has uploaded 303 videos on this channel. And has been watched 16,723,044 times. This channel is still active now. The last post was on April 11,2021, discussing the faith of believers and where God is, which Ifnaldi brought. His last few posts have focused more on fending off terrorist accusations pinned on this group and the topics discussed. Such as, is Salafi radical? jihad in the hands of fools, intel interrogations, and suicide bombings. As for other discussions are almost the same as previous channels, such as theological studies by Yazid bin Abdul Qadir Jawas and Firanda Andirja, and several other studies by Khalid Basalamah. 
IJIK Vol. 11 No. 2 : 134-149

Salafi Puritanism in Indonesia

Ahmad Syamsir et.al

\section{Discussion}

\section{Theological Teachings That Formed the Basis of Salafist Puritanism}

The current reality based on the data we presented above clearly shows the lack of identification of the theology that underlies Salafi puritanism. However, puritanism in the realm of theology is a common phenomenon in religious history. This phenomenon often appears in various formulations in which puritanism is not infrequently associated with renewal (tajdid) as well as purification (Ben-David, 2019). The nature of this group tends to be easy to heresy even to the point of disbelief against groups that oppose them, especially in terms of fiqh. This is what is closely related to theology. The allegations addressed to some of the movements mentioned above are closely related to the exclusive attitude of the Salafi group in holding and viewing the Islamic doctrine of these people claiming themselves as the only group of ahlussunnah, true practitioners of Islam based on the Qur'an and the Sunnah of the Prophet. in accordance with the practices carried out by the Prophet and the Companions, as well as the early generation of Muslims (al-salaf al-salih).

The Salafi relationship with the Wahhābi — as will be discussed hereafter — is in the same spirit of purification (Mathiesen, 2013). This similarity is not a coincidence, as the Salafis have a historical chronology closely related to the Wahhābī. However, not all Salafis are happy to be called Wahhābī. The name of Wahhabism among his followers turned out to be less popular. This is why they lately tend to be nicknamed Salafi or followers of the teachings of salaf scholars (earlier). It is possible that the name of this Wahhabism did not come from the followers of Muhammad Ibn Abd al-Wahhab, but was pinned down by their opponents. This group belongs to the group that most often uses the works created by Ibn Taymiyyah as their main reference. However, this is considered less appropriate in understanding the teachings of Ibn Taymiyyah because the Salafis are considered a new formulation of Wahhabism.

This da'wah movement of the Salafi is known as a da'wah movement with a radical puritan theological ideology. Which is the main agenda is to invite to return to the Qur'an and the Sunnah of the Prophet. Although known as a group of radical puritan Muslims, the Salafi movement is also known as the anti -Hizbiyyah da'wah movement. This movement does not engage in a practical political territory (Naupal, 2019). There are several reasons why the teachings of Ibn Taymiyyah or the Salafis spread faster than the teachings of Ash'ariyah and Shi, ah, in short, this group has the influence and support of several religious organizations, even the Government of Saudi Arabia. This automatic is very conducive to the spread of Salafi teachings openly. Another aspect revealed from this study is the path of the spread of puritan theology through education. Education turned out to be a major mediator in grounding imported theologies, including Salafi Puritanism (Darmalaksana \& Qomaruzzaman, 2020).

This formulation is basically limited by the genealogical relationship of Salafi theological thought, which is continuous from Contemporary figures, then Muhammad Ibn Abd al-Wahhab and Ibn Taymiyyah, to the time of Ahmad Ibn Hanbal in the third century Hijriah. Salafi theological attitudes that have always been leaned on to the salaf or early generations will be tested for their truth by exploring theological doctrines put forward by each of the central figures in the history of Salafi thought. The understanding of theology based on textualism is at the root of all puritans. This can be traced by tracing the genealogy of puritan theology that did not only stop in the eighth century Hijri but the phenomenon has been rooted since the third century Hijri (Watt, 2019). Therefore, the historical aspect of thought becomes an important aspect. Puritan theology is slowly and surely moving into the world of education and society in general. This can be seen from the existence of theological books that have so far developed in ma'had and madrasas. The Ash'ariah Sunni theological books that have been used for centuries are finally starting to 
be replaced because of the renewal and enlightenment of thought. Ash'ariyah-leaning theology begins to fade. It is evident from the symptoms of a decline in academics in Islamic higher education institutions in Indonesia towards the study of Sunni Ash'ariyah theology. The reality of the Salafis as a theological school was actually long before Ibn Taymyah, let alone Muhammad Ibn 'Abd al-Wahhāb. This is by the name Salafi itself, which means the teachings of the previous people. Both Ibn Taymiyah and Muhammad Ibn 'Abd alWahhāb always linked their theological teachings to previous generations of Muslims. The most important fact of this genealogy is that the anābilah school dominated the predecessors of the Salafis. As mentioned earlier, Salafi theology began long before Ibn Taymìyah, during the Abbasid dynasty in Baghdad. At that time, many Hadith experts were victims of government policies that tried to apply Mu'tazilah teachings as official theology (Abdulganiy \& Alhaji, 2020). Several issues were used as tools to execute figures deemed theologically deviant by the Mu'tazilah.

As a puritanical school of theology, Salafi has proven to have a genealogy connected to the Salaf generation, especially to the figure of Ahmad bin anbal. Salafist puritanism is not without cause and background (Adraoui, 2020). The purification movement they carried out was motivated by torture and mistreatment carried out by authorities with opposing "official" theology. For the first time, the revival of the Salafis had begun since the time of Ahmad bin anbal, with the support of the ruler of his time, the Caliph al-Mutawakkil. Then, he experienced a second revival during the time of Ibn Taymiyah but did not get the blessing of the authorities and most of the scholars of his time who were Ash'ariyah. Finally, the resurgence of the Salafis was marked by the movement of Muhammad Ibn Abd al-Wahhāb, who advanced and regained support from the authorities. If the "palace" has become the basis of theological teaching, then other sects and groups will be eliminated. As for theological issues, Salafis always refer to themselves as Ahl al adith waal-Athar or Ahl al-Sunnah wa-al Jamā'ah, although the majority of Sunni scholars who are Ash'arīyah and Mātūrīdīyah do not accept it. Like Ash'arīyah and Mātūrdīyah, Salafi scholars also do not consider the two theological schools to be part of Ahl al-Sunnah wa-al-Jamā'ah.

\section{Relations of Foreign Salafis with Domestic Salafis}

Before discussing the relationship between foreign and domestic Salafis, it would be better if we first know the figures who become liaisons between countries in spreading their teachings. In this case, we will present at least four foreign Salafi figures, such as Muhammad Ibn 'Abd al-Wahhāb (1703-1791 AD) Muḥammad Nāṣir al-Dīn al-Albānī (1914-1999 AD); Ibn al-'Uthaymin (1929-2001 AD); and āliḥ alFawzān (1933-present).

\section{Muhammad Ibn 'Abd al-Wahhab (1703-1791 AD)}

Muhammad Ibn 'Abd al-Wahhāb is a reformer of Salafi theology who was born in 'Uyaynah, one of the cities in Najd. Muhammad Ibn 'Abd al-Wahhāb was born into a very close family with the Turāth Ibn Taym turyah and the anbali school. This reality is evident from two sides: his father as mufti of the anbal school and his brother named Sulaymān Ibn 'Abd al-Wahhāb. His brother once criticized Muhammad Ibn 'Abd al-Wahhāb by writing the book al-Ṣawā'iq al-Ilāhīyah. This book is very thick with quotations from Ibn Taymīyah, but is used as a rebuttal argument against Muhammad Ibn 'Abd al-Wahhāb. In addition, Sulaymān also wrote the book Faṣl al-Khitāb fỉ al-Radd 'alá Muhammad Ibn 'Abd al-Wahhāb with a theme that is not much different from the previous book (Hasyim, 2019).

Sulaymān Ibn 'Abd al-Wahhāb acknowledged his father's admiration for the intelligence of Muhammad Ibn 'Abd al-Wahhāb since childhood. As a teenager, he went on pilgrimage with his father. After that, do rihlah to the Hijaz to meet and learn from the aramayn scholars. 'Abd al-Raḥmān Ibn 'Abd al- 
Lațif who is still a descendant of lu al-Shaykh mentioned that among the scholars who had been his teacher were 'Abd Allāh Ibn Ibrāhīm Ibn Sayf al-Madanī, Muhammad ayāt al-Sindī, Ismā'īl al-' Ajlūnī, 'Alī Afand alDaghistānī and others. He got a diploma of the books of Hadith from them. As for when he moved to Basrah, Mūḥammad Ibn 'Abd al-Wahhāb studied with Muhammad al-Majmū'î ('Abd al-Lațîf, 1972).

Muhammad Ibn 'Abd al-Wahhāb began to spread his understanding of tawhīd since he was domiciled in Basra. His da'wah movement was supported by his teacher Muhammad al-Majmū'ì. However, the da'wah activities of Muhammad Ibn 'Abd al-Wahhāb contradicted most of the Basrah scholars, resulting in his expulsion. He was expelled in the summer to arrive in the region between Basra and Zubayr, severely dehydrated. At that time, someone named Ab umaydān helped him and was taken to Zubayr. From Zubayr, Muhammad Ibn 'Abd al-Wahhāb returned to Najd, canceling his desire to go to Sham. He returned to study with his father, 'Abd al-Wahhab. His father had moved to Huraymala because of a dispute with the new leader of the city of 'Uyaynah, namely Mūhammad Ibn and who was known as Kharfașh. Kharfash dismissed 'Abd al-Wahhāb from the post of mufti and qādī. This incident prompted 'Abd al-Wahhāb to move to Huraymala. In the city of Huraymala, Muhammad Ibn 'Abd al-Wahhāb studied the works of Ibn Taymìyah and Ibn Qayyim al-Jawzìyah. He copied the works of Ibn Taymìyah (Hasyim, 2019).

When he studied the works of Ibn Taymiyah, this is where his mission of preaching began to become more puritanical, so that it tended to cause conflict with other scholars who tended to contradict puritan attitudes. This is as Arrazy Hasyim (2019) explained, who said that the attitude of Muhammad Ibn 'Abd al-Wahhāb was very extreme because he tried to fight something he considered shirk and heresy. So he also had to intersect with other scholars, even with his father. So this forced him to stop his preaching, at least until his father died in $1135 \mathrm{H}$.

\section{Muḥammad Nāṣir al-Dīn al-Albānī (1914-1999 M)}

His full name is Muhammad Nāṣir al-Dīn Ibn Nūḥ Ibn dam Ibn Najātī al-Albānī al-Arna'ūțī. He came from Albania and was born there in $1333 \mathrm{AH}$ or 1914 AD. He was born into a religious family. His father, Nūh Ibn dam, was a 'anaf' mazhab, having graduated from several ma'had schools in Istanbul. After that, his father returned to Albania to teach his knowledge. Sometime later, al-Albānī was forced to immigrate to the Syrian capital Damascus because of Mu revolusion ammad Zūghū's revolution. Al-Albānī considered that this figure followed the revolutionary movement of Kemal Attāt revolution in Turkey (Hamdeh, 2016).

Al-Albānī experienced extraordinary intellectual development while living in Damascus. He began to be interested in the study of Hadith and theology after studying "anaf" fiqh from his father and several unnamed scholars. Previously, he also studied Arabic, namely naḥw, arf, and balāghah to Sa'īd al-Burhānī. He studied the book Marāqī al-Falāh from the figure. In addition, al-Albānī had a formal school at Madrasah al-Is'âf al-Khayrī for the ibtidā'ì (elementary school) level. But he did not finish at the madrasa due to the Syrian people's revolution against the French army. The revolution caused Madrasah al-Is'âf al-Khayrī to burn, so he moved to another Madrasa in the Sārūjah market until he finished (Al-Jabbūrī, 2008).

At this time, al-Albānī came into contact with the thoughts of Muhammad Bahjat al-Baytāār (d. 1367 H), who was known to be inclined towards the Salafis. This is the most important period in understanding the development of al-Albani's thought, which initially tended to the anafi school as his father, then turned to Salafi. In addition, he was also influenced by the ideas of Muhammad Rashīd Ridá. The upheaval of alAlbān's thoughts after receiving enlightenment from the two figures became the cause of a dispute between al-Albānī and his father (Mamdūḥ, 2009). 
His puritanical thoughts caused a lot of controversies. He was at loggerheads with local scholars, causing various unrest in the community due to his fatwas that often attacked groups that he considered to be far from the beliefs of the Salaf scholars. And the ones he attacked the most were the Sufis. As we know that the Sufis are very fond of pilgrimage to the tomb of the saints, even to get closer to the tomb of the saint. He also built a mosque near the tomb of the saint. And this received very sharp criticism from alAlbānī. This is as stated by Maḥmūd Sa'īd Mamdūh (2009), who said that al-Albānī forbade anyone to pray in the mosque where the grave is, not least in the Nabawai mosque where the tomb of the Prophet Muhammad SAW is located. he also made a fatwa so that the Prophet's food should be moved. However, this was strongly opposed by the scholars of Madinah, so that al-Albānī had to leave Madinah and complete his teaching activities in the city.

\section{Ibn al-'Uthaymīn (1929-2001 M)}

Ibn al-'Uthaymn is attributed to his grandfather 'Uthman, who was five generations above him. The actual name is Abū 'Abd Allāh Muḥammad Ibn ālị̣ Ibn Muḥammad Ibn 'Abd al-Raḥmān Ibn 'Uthmān Ibn 'Abd Allāh Ibn 'Abd al-Rahmān Ibn Aḥmad Ibn Muqbil lu Muqbil al-Wuhaybī al-Tamīmī. He was born in 1347 H/ 1929 AD in the city of Unayzah, Saudi Arabia.

Ibn al-'Uthaymn's scientific career began when his teacher 'Abd al-Rahmmān al-Sa'dī was still alive, in 1370 H. He taught at al-Ma'had al-'Ilmī in Unayzah. In 1376 H, 'Abd al-Raḥmān al-Sa'dī died, so he immediately replaced his teacher as an imam, preacher, teacher, and others in the city of Unayzah without leaving al-Ma'had al-'Ilmī. Since then, Ibn al-'Uthaymn was active in teaching at the Jami Mosque and Maktabah al-Wațaniyah until his death. He is also one of the professors at the University of Muhammad Ibn Su'üd al-Qushaym branch. In fact, he was one of those who formulated the learning curriculum of alMa'had al-'Ilmī and the University of Muhammad Ibn Su'ūd. From 1398 to $1400 \mathrm{AH}$, he became a member of the Qushaym branch of the Shar fakultas'ah and Ușūl al-Dīn faculty senate, then was appointed a member of the Hay'at Kibār al-'Ulamā' Kingdom of Saudi Arabia in 1407 H until his death. The pilgrims and pilgrims also felt its influence through alaqah in aramayn during the hajj season (Hasyim, 2019).

The most phenomenal work of Ibn al-'Uthaymn in theology is al-Qawl al-Mufid as a commentary on Muhammad Ibn 'Abd al-Wahhāb's Kitāb al-Tawhīd. In this book, Ibn al-'Uthaymīn defines tawhīd with the theological thought patterns of Ibn Taymyah and Muhammad Ibn 'Abd al-Wahhāb. Tawhịid according to Ibn al-'Uthaymn is the oneness of Allah based on the aspects of rubībīyah, ulūh,yah, and al-asmā' wa-alșifāt. The name Ibn Taymìyah is very often found as his main reference in explaining the text of the Kitāb al-Tawhīd. He criticizes as a contemporary theologian who tends to focus on explaining tawhīd rubūbīyah, thus leaving shirk in terms of ulūhìyah. He is also serious about forbidding rituals performed at the grave. Like his contemporaries al-Albānī, Ibn al-'Uthaymn also rejected the Prophet's grave is considered part of the Prophet's Mosque (Al-'Uthaymin, 2011).

\section{Ṣālihh al-Fawzān (1933-present)}

He was born in Saudi Arabia, September 28, 1933. His parents died when he was little. Then his extended family made him a foster child and educated him with a strict and serious religious upbringing. His first teacher was amūd Ibn Sulaymān al-Tallāl qāọī in the Qușaym region. After that, he continued his formal education at Madrasah Ibtidā'ìyah in Fayșalīyah (1369-1371 H). Then he continued to al-Ma'had al-'Ilmī (at the level of Madrasah Aliyah) in Buraydah (1373-1377 H.). After that, he studied at the University of Muhammad Ibn Su'ūd in the faculty of Shari'ah (1377-1381 H). At the same university, he earned his Masters and Doctoral degrees with a concentration in fiqh. His contact with 'Abd al-'Azīz Ibn 
Bāz was while studying at Riyad. Apart from 'Abd al-'Azīz Ibn Bāz, he studied with Muhammad al-Amīn alShanqị̂ịi, 'Abd Allāh Ibn Ḥumayd, 'Abd al-Razzāq 'Afîfi and others. His scientific career at Riyad began as a teacher at al-Ma'had al-'Ilmī, then became a lecturer at the University of Muhammad Ibn Su'ūd, in the Shar fakultas'ah and Postgraduate faculties, and culminated as a member of the Lajnah al-Dā'imah li- Iftā' waal-'Ilmyah and Hay'ah Kibār al-'Ulamā'. Before his death, 'Abd al-'Azīz Ibn Bāz and Ibn al-'Uthaymīn had advised adhering to the teachings of ālih al-Fawzān (Hasyim, 2019).

ālị̣ al-Fawzān wrote several theological works, such as Sharḥ 'Aqīdah al-Ṭaḥāwīyah which is a commentary on the theology of al-Ta teologiāwī (d. $321 \mathrm{H})$ based on the Salafi tawd trilogy. Like other Salafi figures, āliḥ al-Fawzān also wrote a commentary on Muḥammad Ibn 'Abd al-Wahhāb's Kitāb alTawhīd with the title I'ānat al-Mustafìd bi-Sharh Kitāb al-Tawhịd. These two master books are indeed a barometer of the validity of a Salafi figure. Therefore, there is no other Salafi figure except sticking to the two books.

In addition, he also wrote al-Irshād ilá Sharḥ al-I'tiqād wa-al-Radd 'alá Ahl al-Shirk wa-al-Ilhāa regarding the concept of the true faith and its difference with shirk and ilhād (kufr). He also wrote a separate book on monotheism with the title 'Aqìdat al-Tawhìd. This book is a summary of theological expressions extracted from the works of Ibn Taymīyah, Ibn Qayyim al-Jawzìyah, Muhammad Ibn 'Abd alWahhāb, and his followers. He criticizes in it what he calls al-tayyārāt al-munḥarifah (deviant teachings) such as ilhāad, tasawuf, rahbanah asceticism (such as rāhib), qubūrīyah wathanīyah (pagan grave worshipers), and heresy. It is in this book that alih al-Fawzān very often mentions salaf theology as must be taught. In the first chapter, he openly mentions that theological ambiguity can be purified in many ways, including teaching Salafi books and avoiding books of deviant schools such as Sufis, heretics, Jahmyah, alMu'tazilah. , Ash'arīyah, Mātūrīdīyah, and others except to the extent of criticizing them (Al-Fawzān, 2017).

\section{The Salafi figures we will discuss are Salafi figures in the country, such as Abdul Hakim Abdat and Khalid Basalamah.}

\section{Abdul Hakim Abdat}

An Indonesian Salafi figure who is very puritan in conveying his message is Abdul Hakim Abdat. The phenomenon of Abdul Hakim Abdat needs to get more attention. This is because he is not a student. Abdul Hakim Abdat never received formal Islamic education, except at the LPBA (Arabic Language Education Board) language course institution in 1980. This institution was the forerunner of LIPIA five years later. After LIPIA was established, Abdul Hakim Abdat did not meet the administrative requirements to enter LIPIA. Then, Abdul Hakim Abdat "imitated" what al-Albānī did by reading the books available in the LIPIA library. A few years later, he was often involved in LIPIA library scientific projects. Shortly after that, Abdul Hakim Abdat opened the study of Hadith in several places. The interaction with LIPIA lecturers most likely inspired Abdul Hakim Abdat to tend to Salafi thinking (Hasyim, 2019).

In this case, Abdul Hakim Abdat admitted that he had no influential teachers other than the books he read. This is very similar to al-Albanī, so, naturally, non-sectarian, anti-theological attitudes and assessments of the quality of Hadith are contagious to him. In addition to al-Albānī, he was heavily influenced by the works of 'Abd al-'Azīz Ibn Bāz. The influence of al-Albānī in the thought of Abdul Hakim Abdat is very clear in many ways. He referred to al-Albānī as a "great scholar of Hadith" and an "Imam." Just as al-Albānī declared himself to be non-sectarian, Abdul Hakim Abdat also admitted to being nonsectarian. The influence of al-Albānī was not only in thought but also in the style of language and in conveying criticism. Abdul Hakim Abdat is similar to al-Albānī in naming the people he criticizes. This can 
be seen from judging Quraish Shihab as a very ignorant person in Hadith and tafsir. In theology, the thought of 'Uthmān Ibn Sa'īd al-Dārimī, Ibn Taymīyah, al-Dhahabī, and also al-Albānī has always been a reference. Therefore, in the book of al-Masa'il, Abdul Hakim Abdat seriously discusses Jihad al-'ulū as the nature of God. In fact, He asserted that anyone who does not believe that God is in the sky does not belong to the believer (Abdat, 2008).

As usual, Abdul Hakim Abdat's puritanical attitude made him issue a lot of controversial fatwas that slammed the customs that had prevailed in Indonesia, causing friction with local organizations, such as NU. As Abdat (2008) himself said, the performers of rituals in the grave and hawl as grave worshipers or "kuburiyyun". In addition, he also considers the stream of ash'ari'ah as a deviant and misguided stream.

\section{Khalid Basalamah}

Khalid Basalamah was born in Makassar, May 1, 1975, with the full name Khalid Zeed Abdullah Basalamah. The basalamah title at the end of his name is taken from the clan name. The Basalamah clan is one of the surnames taken from the Arabic Hadramaut, which refers to the family name of Arab descent. Who came from Hadramaut, Yemen. It is located in the southern part of the Arabian Peninsula. The naming of the clan was chosen based on the tribe, place, origin, history, and also the habits and characteristics of the ancestors.

He is known as an Ustadz with a firm and polite delivery of lectures. He also often fills tausiyah programs on da'wah televisions such as Insan TV, Wesal TV, Rodja TV, etc.

He spent his childhood in Makassar. After completing his education in junior high school, Khalid Basalamah then left for Medina, Saudi Arabia, and continued his high school education there in the 1990s. Every day what they do is study religion, such as the verses of the Qur'an and the Hadith of the Prophet. Another activity that Khalid Basalamah does is go to school or go to the Prophet's Mosque to worship. He also visits Indonesian people who live there. Khalid Basalamah completed his undergraduate education at the University of Medina, Saudi Arabia). After that, he returned to Makassar. For master's level education, he completed his master's degree at the Muslim University of Indonesia in (Makassar). And he completed his doctorate or doctoral degree at the Muslim University of Indonesia in (Makassar). Khalid Basalamah currently spends most of his time as a lecturer. He was filling Islamic studies from mosque to mosque. In delivering his da'wah, he always based on the Qur'an and Hadith as well as from the understandings of the companions and scholars.

Just like other Salafi figures, Khalid Basalamah also often said controversial things. So that sometimes, it causes some friction with other mass organizations, such as NU. He was even expelled by Banser when he wanted to deliver a lecture at the KH Mosque. Hasyim Asy'ari on Friday, May 4, 2018, as reported by the cnnindonesia.com site. And this also received a response from Cholil Nafis, who said that da'wah must be full of tolerance and mutual respect so as not to be noisy (FHR, 2018).

Thus, it means that the relationship between foreign Salafi leaders and domestic Salafi leaders is very clear. They have the same reference, namely referring to the books of Ibn Taimiyah. And they also tend to give Sharh to these books, so they have the same understanding. This results in an understanding of the same faith, such as the prohibition of worship rituals in graves, the eradication of heresy, and also being very intolerant of the worship of the surrounding Muslim community. 
IJIK Vol. 11 No. 2 : 134-149

Salafi Puritanism in Indonesia

Ahmad Syamsir et.al

\section{How do they influence the community, especially the younger generation, so that many sympathize with the Salafi Da'wah?}

The results of observations on YouTube show that there are relatively many enthusiasts of Salafi studies or da'wah. The channel that has the most subscribers among the channels that we research is the Minang tauhid channel. This channel has 138 thousand subscribers (maybe it has increased) and has been watched as many as 16,723,044 times, in this channel which is becoming much in demand by people because the videos uploaded discuss a lot of current issues, such as, for example, allegations of terrorists being pinned to their group when terrorist incidents were rampant recently, this was reviewed in detail even though it was only in the form of short videos, the average video being 10 minutes long. This is also, of course, what has resulted in attractiveness for young people. The author assumes that young people who are enthusiastic or growing their Islamic spirit will be very interested in a study that discusses the latest phenomena about Islam. Not only that, the studies published in the channel that we are researching discuss more light-hearted studies, such as dating and cases that a teenager generally experiences. I think. For example, a teenager has just been dumped by his partner, and he has lost his enthusiasm in living his days as a result of the loss of a lover he loves. In this case, he might be interested in a Salafi study because in Islam, according to them, "dating is haram, so leave it." These words are like a breath of fresh air for him as a teenager who has lost his lover, as if giving new hope that what has happened to him is a good thing. God has blessed him for separating him from his ex. Young people will be more interested in the Islamic issues discussed closely related to their daily lives, theological issues, ort fiqh ikhtilaf for young people tend to be very boring and less interesting to follow. And there is one phenomenon that is rife lately in our country, namely, the phenomenon of hijrah, this phenomenon is much loved by young people. The things that I have expressed are in line with what was expressed according to Muntazori and Sunarto (2019): "The segmentation of the hijrah movement for the millennial Muslim generation is a form of approaches used, namely using da'wah material according to the needs of the younger generation, da'wah on social media becomes The creative form of da'wah content creators can introduce light da'wah through quotes that aim to reach the hearts and minds of followers." And Annisa (2018) also argues that "the younger generation who tend to use social media as a concept of religious discourse with the convenience of clicking news labeled Islam, online recitations, including being loyal followers of accounts labeled ustadz or slang ulema can no longer be avoided.

\section{CONCLUSION}

Salafis are one of the groups in Islam that are known for their puritanical attitudes. This can not be separated from the thoughts of Ibn Taimiyah, Muhammad Ibn 'Abd al-Wahhāb, and also Muhammad Nāșir al-Dīn al-Albān considered who is considered the High Priest for them. His thinking tends to be puritanical, making him arguing with other groups in different directions, even with his father or closest people. This condition continues today, where many Salafi clerics also have less harmonious relations with several Islamic groups in Indonesia, such as Nahdlatul Ulama and the Islamic Defenders Front. This research makes us understand how rich the schools in Islam are. And this has implications for the attitude we must take, namely the attitude of respecting opinions. We can attack someone's ideas but don't let them because we have different ideas. We attack personally. This is where the role of the Government, in this case, the Ministry of Religion, along with the MUI and other religious organizations, is needed to maintain harmony in religion and nation, without putting aside differences of thought in understanding a religious text. For this reason, maturity in religion is needed so that attitudes that have the potential to divide Muslim 
brotherhood can be avoided. We also encourage various parties, especially academics, to seriously review various thoughts in Islamic treasures, especially regarding theological issues. In our opinion, this needs to be done so that the wider community can understand the nature of each theological school so that they can avoid the "seduction" of deviant sects that can threaten their faith.

\section{REFERENCES}

'Abd al-Lațîf, 'Abd al-Raḥmān. (1972). Mashāhīr 'Ulamā' Najd wa-Ghayrihim. Dār al-Yamāmah. Abdat, A. H. (2008). Risalah Bid'ah. Maktabah Mu'awiyah.

Abdulganiy, R., \& Alhaji, R. A. (2020). The Nexus between the KhawÄ rij Theological Misconception of Äam $\mathrm{Än}$ (Faith) and Boko Haram Insurgency in Nigeria. Jurnal Usuluddin, 48(1), 113-146.

Adraoui, M.-A. (2020). Salafism Goes Global: From the Gulf to the French Banlieues. Oxford University Press.

Al-'Uthaymīn, I. (2011). al-Qawl al-Mufìd 'alá Kitāb al-Tawhìd. Dār Ibn al-Jawzī.

Al-Fawzān, Șalih. (2017). 'Aqìdat al-Tawhìd. Yayasan As-Shafwah.

Al-Jabbūrī, A. Ḥusayn. (2008). Juhūd al-Imām al-Albānī Nāṣir al-Sunnah fi Bayān 'Aqīdat al-Salaf alSẵlihịn fì al-İmān bi-Allāh Rabb 'Ālāmīn. Dār al-Atharīyah.

Ali, K., \& Minxing, H. (2021). Muslims preaching movements in British-India: An appraisal of the Tablighi Jamaat and its competitors. Liberal Arts and Social Sciences International Journal (LASSIJ), 5(1), 356-371.

Annisa, F. (2018). Hijrah Milenial: Antara Kesalehan dan Populism. MAARIF, 13(1), 38-54.

Baskara, B. (2017). Islamic puritanism movements in Indonesia as transnational movements. DINIKA: Academic Journal of Islamic Studies, 2(1), 1-22.

Ben-David, J. (2019). Puritanism and modern science: a study in the continuity and coherence of sociological research. In Comparative Social Dynamics (pp. 207-223). Routledge.

Chozin, M. A. (2013). Strategi Dakwah Salafi di Indonesia. Jurnal Dakwah, 14(1), 1-25.

Darmalaksana, W., \& Qomaruzzaman, B. (2020). Teologi Terapan dalam Islam: Sebuah Syarah Hadis dengan Pendekatan High Order Thinking Skill. Khazanah Theologia, 2(3), 119-131.

FHR. (2018). Ditolak GP Ansor, MUI Minta Khalid Basalamah Instrospeksi. CNN Indonesia. https://www.cnnindonesia.com/nasional/20180505184058-20-295980/ditolak-gp$\% 09$ ansor-mui-minta-khalid-basalamah-instrospeksi

Hamdeh, E. (2016). The formative years of an iconoclastic Salafi scholar. The Muslim World, 106(3), 411.

Hasyim, A. (2019). Teologi Muslim Puritan: Genealogi dan Ajaran Salafi. Maktabah Darus-Sunnah.

Hidayat, D. (2012). Gerakan Dakwah Salafi di Indonesia: Studi tentang Kemunculan dan Perkembangannya di Era Reformasi. MASYARAKAT: Jurnal Sosiologi, 17(2).

Kaelan, H. (2010). Metode Penelitian Agama Kualitatif Interdisipliner. Yogyakarta: Paradigma.

Madali, E. (2021). Reformisme Hukum: Pengamalan Agama Perspektif Salafi Wahabi. Res Justitia: Jurnal Ilmu Hukum, 1(1), 125-156.

Maksum, A., Mas'udah, S., Fuad, A. N., \& Wahyuni, E. N. (2020). Ideological Conflicts Between Radical and Moderate Islamic Organizations in Indonesia. Journal of Talent Development and Excellence, 12(1), 2248-2261.

Mamdūh, M. S. (2009). Ittijāhāt al-Hadīthīyah fì al-Qarn al-Rābi'. Dār al-Bașā’ir.

Mathiesen, K. (2013). Anglo-American 'traditional Islam'and its discourse of orthodoxy. Journal of Arabic and Islamic Studies, 13, 191-219.

Muntazori, A. F., \& Sunarto, B. (2019). A Representation of Hijrah in Visual Da'wah Media on Instagram. IICACS: International and Interdisciplinary Conference on Arts Creation and Studies, 1, 174-184. 
IJIK Vol. 11 No. 2 : 134-149

Salafi Puritanism in Indonesia

Ahmad Syamsir et.al

Naupal, N. (2019). Reading Islamic Radical Networks in West Java and Jakarta and Its Relationships with Islamic Trans-National. International Journal of Multicultural and Multireligious Understanding, 6(9), 100-110.

Palmer, R. E. (1969). Hermeneutics: Interpretation Theory in Schleiermacher, Dilthey, Heidegger, and Gadamer. Northwestern University Press.

Putuhena, M. S. (2007). Historiografi Haji Indonesia. LKIS PELANGI AKSARA.

Watt, W. W. M. (2019). Islamic philosophy and theology. Edinburgh University Press.

Zargar, C. (2014). The Hanbali and Wahhabi Schools of Thought as Observed Through the Case of Ziyarah. The Ohio State University. 